\title{
The Eszter Hangos Cosmetic Studio: Finding the Right Strategy to Marketing
}

\author{
Manyiu Lee ${ }^{1 *}$ Xi Zhou ${ }^{2 *}$ Runzi Liu ${ }^{3}$ \\ ${ }^{1}$ Business School, The Chinese University of Hong Kong, Hong Kong, 999077, China, mandylee200082@gmail.com \\ ${ }^{2}$ Dublin School, Dublin NH, 03444, America, zhouxi2621@gmail.com \\ ${ }^{3}$ Shandong Zibo Shiyan High School, Shandong, 255000, China, 3352846559@qq.com
}

\begin{abstract}
A right marketing strategy is significant since the success of marketing is closely related to the survival interests of enterprises. Customer needs are the starting point of marketing, and meeting customer needs is the ultimate goal of marketing. In the 21 st century, enterprises are facing with severe challenges due to COVID-19. How to survive in the cruel economic environment and achieve a better financial situation? The role of marketing is important, which marketers need to consider the features of new products or services, determine the prices, where to sell their products or services, and how much to spend on advertising, sales, Internet, etc. Thus, this paper is going to review a case study and find the right approach to promotion and marketing for the case character, aiming at helping her cosmetic studio to be more profitable and competitive in the future. We will first have an analysis of SWOT of the studio, mission $\&$ vision and the macro and microenvironment, following by marketing strategy, alliances and organizational analysis.
\end{abstract}

Keywords: SWOT, mission\&vision, macro\&microenvironment, marketing strategy, alliances, organizational analysis.

\section{INTRODUCTION}

The case describes the process of Eszter's cosmetic studio from losing money to making money. Due to the failure of job searching, Eszter decided to set up her own cosmetic studio in Pécs. However, she did not know how to do marketing at the beginning of the business [1]. The high prices made many consumers reluctant to visit her studio. Later, her friends and she carried out appropriate marketing strategy, which led to a significant increase in turnover. In the case, there are two main problems which can be highlighted: The lack of appropriate pricing and the absence of a marketing strategy at the beginning of a business. How deep should market analysis be? What are the best ways to promote a small beautician's studio? We now assume the role of entrepreneurs and develop marketing strategy for Eszter's cosmetic studio to help it reach more customers and have a good prospect for development in the future.

\subsection{SWOT ANALYSIS}

\begin{tabular}{|l|l|}
\hline $\mathbf{S}$ & $\begin{array}{l}\text { 1. Various discounted prices and good service environment } \\
\text { 2. High cosmetic quality and service quality } \\
\text { 3. Excellent beauticians } \\
\text { 4. Support from friends and family }\end{array}$ \\
\hline $\mathbf{W}$ & $\begin{array}{l}\text { 1. New entrants to the market } \\
\text { 2. Even though Eszter provides discounts, the original prices of the services are high } \\
\text { 3. Lack of business management knowledge }\end{array}$ \\
\hline $\mathbf{O}$ & $\begin{array}{l}\text { 1. The attractive discounts } \\
\text { 2. Now people of all ages are in increasing demand for beauty salons }\end{array}$ \\
\hline $\mathbf{T}$ & $\begin{array}{l}\text { 3. People's income generally increases which more and more can afford the price of cosmology } \\
\text { 2. Increasing number of competitors }\end{array}$ \\
\hline
\end{tabular}




\subsection{MISSION \& VISION}

The mission of the cosmetic studio is to provide every customer with world-class beauty services and the vision is to be the best, most trusted and admired beauty services studio in Pecs.

\subsection{MACROENVIRONMENT \& MICROENVIRONMENT ANALYSIS}

\subsubsection{MACROENVIRONMENT ANALYSIS}

Demographic: As the fifth largest city in Hungary, with many tourist attractions and large population, Pécs has nearly 260 thousand people in 2021.

Economic: As a developed country, Hungary has good economic development with a per capita national income of $\$ 16,140$, which has increased by $\$ 2,950$ in ten years.

Sociocultural: With the progress of the country, people's income has increased, and their consumption has changed from the consumption of basic needs to the consumption focusing on spiritual enjoyment. In addition, women's pursuit of beauty can be clearly seen over time.

Political/legal: Hungary has taken some measures to optimize the business environment, such as tax reform, protection of employee welfare and provision of financial support. Hungary has no restriction on beauty

industry which give the beauty salon a large development space.

Technological: Beauty industry has experienced more than ten years of development, which the technology and equipment have been mature. From basic skin care, spa professional health care to stem cell beauty, both raw materials and beauty facilities are gradually standardized.

\subsubsection{MICROENVIRONMENT ANALYSIS}

Competitors: There are lots of direct competitors in the surrounding. Customers can easily switch to others.

Suppliers: Many of the suppliers are joined by wellknown brands, who have stable market positions. There are many buyers of their products, therefore every single buyer will not become an important customer. Meanwhile, due to the increase of beauty salons, this leads to limited supply of hot products, which increases the bargaining power of suppliers.

Substitutes: The substitutes of facial beauty care can be cosmetics, skin care products and so on. The substitutes of slimming services can be weight loss food and weight loss equipment e.g. fat exercise machine.

Entry barriers: Starting up a small cosmetic studio does not need huge investment. The threshold of entering the industry is low. There is no government restrictions.

\section{STRATEGIC ANALYSIS}

Table 2 Advertising Strategy of Eszter's Cosmetic Studio

\begin{tabular}{|c|c|c|c|c|c|c|c|}
\hline Time & \multicolumn{3}{|c|}{ Week } & \multicolumn{4}{|c|}{ Weekend } \\
\hline $\begin{array}{l}\text { Consumer } \\
\text { Group }\end{array}$ & $\begin{array}{c}\text { Non-Working } \\
\text { Class }\end{array}$ & $\begin{array}{c}\text { 30-50 } \\
\text { Woman }\end{array}$ & Man & $\begin{array}{c}\text { Working } \\
\text { Class }\end{array}$ & $\begin{array}{l}\text { Young } \\
\text { Customers } \\
(<\mathbf{3 0})\end{array}$ & $\begin{array}{c}\text { 30-50 } \\
\text { Woman }\end{array}$ & Man \\
\hline Pre-work & \multicolumn{3}{|c|}{$\begin{array}{l}\text { Hand out leaflets nearby } \\
\text { Make own website for publicity } \\
\text { Advertise on car radio } \\
\text { Advertise in the fashion section of newspaper } \\
\text { Look for handsome hairdressers and salesmen } \\
\text { Look for beautiful service girl and door model }\end{array}$} & \multicolumn{4}{|c|}{$\begin{array}{l}\text { Advertise in libraries } \\
\text { Make own website for publicity } \\
\text { Perform outside the door to attract customers } \\
\text { Declare the efficiency of the services and save time } \\
\text { Look for handsome hairdressers and salesmen } \\
\text { Look for beautiful service girl and door model }\end{array}$} \\
\hline $\begin{array}{c}\text { Special } \\
\text { appointments }\end{array}$ & \multicolumn{7}{|c|}{$\begin{array}{l}\text { Specially appointed marketing through exclusive and high-end channels, magazines and media. The } \\
\text { focus of the special appointment is to provide services to high-income people who require exclusive } \\
\text { services. Secondly, we should provide services with different needs for the disabled and obese people. }\end{array}$} \\
\hline
\end{tabular}

As can be seen from Table 2, for the advertising strategy we divide the time into two part - weekdays and weekends. The consumer groups are divided into nonworking class, 30-50 woman and man on weekdays and working class, youth (<30), 30-50woman, man on weekends. For the pre-work on weekdays, we can advertise on the car radio and the fashion section of the newspaper. Also, we can hand out leaflets near the schools for parents who waiting for their children. On weekends, we can do advertising in libraries and make their own website for publicity or organize public events, such as make-up competitions to attract the potential customers. In addition, we are looking for handsome hairdressers and salesmen- For female customers and looking for beautiful service girl and door model- For male customers for both pre-work and after-work time. For the after-work time on weekdays, we may need to first declare the efficiency of the service and save time to 
show our efficiency. Then, send video or vlog of real working state on social software. Using neon lights at night is also a good method. For the after-work time on weekends, we can hand out leaflets in shopping malls. And recommend the website to customers, let them fill in their experiences and feelings and show it to other potential consumers. The focus of the special

Table 3 Various Targeted Services provided by Eszter's Cosmetic Studio

\begin{tabular}{|c|c|c|c|c|c|c|}
\hline Time & \multicolumn{3}{|c|}{ Week } & \multicolumn{3}{|c|}{ Weekend } \\
\hline $\begin{array}{l}\text { Consumer } \\
\text { groups }\end{array}$ & $\begin{array}{l}\text { Students and } \\
\text { young people }\end{array}$ & $\begin{array}{l}\text { Ordinary } \\
\text { working ladies }\end{array}$ & $\begin{array}{l}\text { Women over } 40 \text { and } \\
\text { affluent women }\end{array}$ & $\begin{array}{l}\text { Young } \\
\text { people }\end{array}$ & $\begin{array}{l}\text { Ordinary } \\
\text { working ladies }\end{array}$ & $\begin{array}{l}\text { Women } \\
\text { over } 40\end{array}$ \\
\hline Pre-work & $\begin{array}{l}\text { Economical se } \\
\text { 1.Small bubble } \\
\text { 2.Manicure } \\
\text { 3.Make-up } \\
\text { 4.Moisturizing } \\
\text { 5.Blackhead re } \\
\text { 6. Normal barb } \\
\text { 7. Routine faci } \\
\text { 8. Anti-pimple }\end{array}$ & $\begin{array}{l}\text { es e.g. } \\
\text { e } \\
\text { val } \\
\text { ig } \\
\text { are } \\
\text { atment }\end{array}$ & $\begin{array}{l}\text { More expensive and } \\
\text { wellness therapy } \\
\text { services e.g. } \\
\text { 1. skin rejuvenation } \\
\text { 2. anti-wrinkle care } \\
\text { 3. Whitening treatment } \\
\text { 4. Body treatments e.g. } \\
\text { Lymphatic } \\
\text { detoxification, } \\
\text { ovarian } \\
\text { maintenance, } \\
\text { kidney maintenance } \\
\text { etc. }\end{array}$ & $\begin{array}{l}\text { All serv } \\
\text { people } \\
\text { (all seg1 } \\
\text { without } \\
\text { Provide } \\
\text { services } \\
\text { custome }\end{array}$ & $\begin{array}{l}\text { s provided for all } \\
\text { its come on the } \\
\text { ecific timing) } \\
\text { rresponding } \\
\text { cording to the sit }\end{array}$ & $\begin{array}{l}\text { rinds of } \\
\text { ation of }\end{array}$ \\
\hline After work & \multicolumn{3}{|c|}{$\begin{array}{l}\text { 1.Body treatments for work fatigue e.g. holistic massage, } \\
\text { spa, etc. } \\
\text { 2.Those who prepare for dating or events: quick hair, } \\
\text { waxing, lash lift, etc. }\end{array}$} & & & \\
\hline $\begin{array}{c}\text { Special } \\
\text { appointments }\end{array}$ & \multicolumn{6}{|c|}{$\begin{array}{l}\text { 1. Tailor the beauty plan for customers in need } \\
\text { 2. Home beauty treatments for VIP customers }\end{array}$} \\
\hline
\end{tabular}

As can be seen from Table 3, regarding services offering we do some segmentation as to provide targeted services to targeted customers. (week \& weekend, wealthy group and non-wealthy group, pre-work and after work). In work days, we would provide different packages to wealthy and non-wealthy groups before they work, for example economical services are provided to non-wealthy group including small bubbles, manicure, make-up, moisturizing care, blackhead removal and so on. Regarding the wealthy group, we would provide the more expensive ones such as skin rejuvenation, antiwrinkle care and body treatments such as lymphatic detoxification, ovarian maintenance, kidney appointment is to provide services to high-income people who require exclusive services. Secondly, we are going to provide services with different needs for the disabled and obese people. maintenance and so on. After work, we would provide body services for work fatigue including holistic massage and spa. For those who have dating or events after work, we would provide quick hair, waxing, lash lift and so on. On the weekend, all the services would be provided to all kinds of people since all segments come on the weekend without specific timing. Thus, we would provide corresponding services according to the situation of customers. Finally, we are going to have some special appointments such as home beauty treatments to VIP customers.

Table 4 Add-on Services provided by Eszter's Beauty Studio

\title{
Add-on Services
}

\author{
Volumizing hair treatment for a thicker looking hair: Add to the blow dry service \\ Hair colour glossing service: Add to the colour service \\ Head massage treatment: Add on top of the shampooing service \\ Nail art add-on and anti-aging hand mask: Add to the manicure treatment \\ Nose wax service: Add to the barbering service
}

As can be seen from Table 4, we try to provide some add-on services in order to be differentiated from competitors. For example, volumizing hair treatment for a thicker looking hair is added to the blow dry service. 
Hair color glossing service is added to the color service Head massage treatment is added on top of the shampooing service. Nail art add-on and anti-aging hand mask are added to the manicure treatment. Nose wax is added to the barbering service [2].

Table 5 General Marketing Initiatives of Eszter's Cosmetic Studio

\begin{tabular}{|c|c|}
\hline \multicolumn{2}{|r|}{ General marketing initiatives } \\
\hline 1 & $\begin{array}{l}\text { Free Skin Test \& } 15 \text { Minutes Massage } \\
\text { Provide customers with free skin test before beauty treatments, give them relevant suggestions, and provide a free } \\
15 \text { mins massage service after the beauty treatments }\end{array}$ \\
\hline 2 & $\begin{array}{l}\text { Friends/Family Package } \\
* 3-5 \text { people come together will be provided } 10 \% \text { discount } \\
*>5 \text { people come together will be provided } 20 \% \text { discount }\end{array}$ \\
\hline 3 & $\begin{array}{l}\text { Bring a Friend } \\
\text { Give bonus to those who introduce friends coming to the salon. For example, introducing one friend can get free } \\
\text { facial care for once or } \$ 15 \text { off for next visit. Also, there is a } 10 \% \text { off for every friend who comes to the salon and } \\
\text { mentions the client's name [3]. }\end{array}$ \\
\hline 4 & $\begin{array}{l}\text { Make the Wait Interesting } \\
\text { *Provide free fruits and snacks to those who are waiting in the waiting area during peak hours } \\
\text { *Provide them with magazines, newspapers and books to keep them engaged with the salon's surrounding and make } \\
\text { it convenient for them to kill time [4]. }\end{array}$ \\
\hline 5 & $\begin{array}{l}\text { Birthday Promotions } \\
\text { Ask clients for their birthday and track when their birthdays are. Then send out birthday promotions to show the } \\
\text { salon's appreciation like a discounted blowout or makeup session. }\end{array}$ \\
\hline 6 & $\begin{array}{l}\text { Online Booking } \\
\text { Online appointment booking feature is handy for a working person to schedule their downtime and this also ensure } \\
\text { that there is no customer waiting in the waiting area for long time [4]. }\end{array}$ \\
\hline 7 & $\begin{array}{l}\text { Engage in Video Marketing on Social Media } \\
\text { Create some videos showing the whole process of making up for clients as well as post before and after image. Invite } \\
\text { more people "behind the scenes" to watch their stylists' work. }\end{array}$ \\
\hline 8 & $\begin{array}{l}\text { Festival Gifts } \\
\text { During some festivals, prepare small gifts to their clients, for example, giving roses or chocolates to customers at } \\
\text { Valentine's Day. }\end{array}$ \\
\hline 9 & $\begin{array}{l}\text { Offer Flash Sales on Twitter } \\
\text { One of the good marketing ideas to attract customers. Twitter is a good place to advertise. Send out a tweet like "\$10 } \\
\text { manicure services for anyone willing to let our best new addition show off her skills!" }\end{array}$ \\
\hline 10 & $\begin{array}{l}\text { Encourage Products Sales } \\
\text { Product can be another stream revenue. Advertise sales on products combination with a service. For example, } 50 \% \\
\text { off a shampoo and conditioner combo with any cut. Can also make the products available online through an online } \\
\text { shop. }\end{array}$ \\
\hline 11 & $\begin{array}{l}\text { Capture Clients' Feedback } \\
\text { Collect feedback on social media or their websites regularly. Then take a couple of hours every month to go through } \\
\text { it all and try to spot themes of common feedback to act on. }\end{array}$ \\
\hline
\end{tabular}

3. Alliance with competitors: Easy to calculate the

\section{SUPPORTING ELEMENTS}

\subsection{ALLIANCES}

1. Cooperate with local Social Media: Invite local famous TIKTOK blogger to try the service/ Having our vlog account

2. The downtown (centre of the town) has the greatest visitor flow rate: Free advertising \& more customers (Golden time: 17:30-22:30 during workday 13:30-16:30 during weekend) acceptable price, make discount and enhance promotional plans

4. Three supplier factories: Cooperate with one of them and share profits (Biggest one in the upper central of Pécs)

\subsection{ORGANIZATIONAL ANALYSIS}

1. Small but delicacy (housing price in Pécs: $\$ 12500 /$ square meters)

2. Price Setting: Using discount instead of price decrease

3. Focus on advertising on social media at first 
4. Let friends of the team try freely, use them to advertise

5. Public praise are free advertising after the start of the market

6. One manager, one beauty salon. Manager report to the CEO

7. New tech updates timely

\section{CONCLUSION}

The purpose of this study can be understood as showing the importance of marketing strategy analysis, which Eszter has to seriously study the surrounding environment, understand the characteristics of customers, identify the target consumer groups, and enhance promotional plans in reference to our proposed marketing strategy by advertising in the way of group segmentation, offering services with various discounts and promotional activities, providing add-on services and taking general marketing initiatives. This may be considered a promising aspect of the studio reaching more customers and increasing sales in the future. In future work, investigating market demand including consumer demand, consumer behavior, consumer income and consumption structure might prove important. In addition, market supply, marketing factor and market competition investigation might prove important areas for future research.

\section{REFERENCES}

[1] Berra, A.G., Cruz, A.B., et al. (2020) The Eszter Hangos cosmetic studio: Finding the right approach to promotion. In: Kunev, S., Galanakis, K., Gkiourka, P. (Eds.), Case studies book on Entrepreneurship and Innovation \& Business creation and management. Ruse University, Svilen Kunev. pp. 27-29.

[2] Hallberg, J. (2021) 41 Best Salon Marketing Ideas, Promotions \& Strategies 2021. https://thesalonbusiness.com/salon-marketingideas/

[3] Ward, R. (2019) Marketing Strategies for Salons \& Salons \& Spas. https://www.gettimely.com/thesource/salon-marketing/marketing-strategies-forsalons-spas/

[4] Brian, M. (2020) 50 Best Marketing Strategies for Beauty Salon Business Growth. https://www.valueappz.com/blog/50-best-salonmarketing-strategies/ 